\title{
COMPARISON OF THE EFFECTIVENESS OF CONTEXTUAL, PROBLEM SOLVING, AND SCIENTIFIK APPROACH OT COOPERATIF SETTING IN MATHEMATICS LEARNING OF CLASS VII STUDENTS AT SMPN ACCREDITATION A
}

\author{
Ahmad Syamsuadi ${ }^{1)}$, Muhammad Arif Tiro ${ }^{2)}$, Muhammad Darwis ${ }^{3)}$ \\ ${ }^{1}$ Prodi Pendidikan Matematika PPS UNM \\ ${ }^{2,3}$ Universitas Negeri Makassar \\ ${ }^{1}$ E-mail : ahmadsyamsuadi36@gmail.com
}

\begin{abstract}
This study is experiment research, which aimsat examining the level of target achievement of students' learning result taught by using contextual approach of cooperative setting, scientific approach of cooperative setting, and problem solving approach of cooperative setting based on (a) the posttest score of students, (b) improvement of students' learning result, and examining the effectiveness of contextual approach of cooperative setting, scientific approach of cooperative setting, and problem solving approach of cooperative setting in Rectangular Flat Surface and Triangle Flat Surface Material of Clas VII studens at SMPN Accreditation A in Makassar based on (a) students' learning achievement, (b) students' learning activities, and (c) studens' response. The population of the study were the entire students of class VII at SMPN Accreditation A in Makassar of academic year 2015/2016; whereas, the samples of the study were 3 school taken ramdomly which were given treatment in Mathematics learning by applying contextual approach of cooperative setting, scientific approach of cooperative setting, and problem solving approach of cooperative setting. Before learning was conducted, the pretest was given beforehand to three schools. Afterwards, learning was conducted by applying contextual approach of cooperative setting, scientific approach of cooperative setting, and problem solving approach of cooperative setting in the experiment class. The result of the study reveals that all of approaches are in fairly effective category with the effectiveness level of each approach is as follows: contextual approach of cooperative setting is $E=3.42$, the scientific approach of cooperative setting is $\mathrm{E}=3.20$, problem solving approach of cooperative setting is $E=3.32$. The contextual approach of cooperative setting is more effective than scientific approach of cooperative setting, and problem solving approach of cooperative setting in Mathematics learning of class VII students at SMPN Accreditation A in Makassar.
\end{abstract}

Keywords: contextual approach, problem solving approach, scientific approach and effectiveness

\section{PENDAHULUAN}

Kecanggihan Teknologi yang semakin berkembang sangatlah membutuhkan Sumber Daya Manusia (SDM) yang berkualitas. Hal tersebut mutlak diperlukan, karena akan menjadi pondasi utama pembangunan bangsa Indonesia yang mandiri dan berkeadilan, serta menjadi jalan keluar bagi bangsa Indonesia dari multi dimensi krisis, ketinggalan teknologi, kemiskinan, dan kesenjangan ekonomi.

Sumber Daya Manusia (SDM) yang berkualitas dapat dibentuk melalui pendidikan, karena melalui pendidikan diyakini akan dapat mendorong 
memaksimalkan potensi siswa sebagai calon Sumber Daya Manusia (SDM) yang kreatif untuk dapat bersikap kritis, logis dan inovatif dalam menghadapi dan menyelesaikan setiap permasalahan yang dihadapinya. Hal tersebut sejalan dengan pendapat Sumarmo (Kurniawan 2006:1) yang menyatakan bahwa pendidikan matematika sebagai proses yang aktif, dinamik, dan generatif melalui kegiatan matematika (doing math) memberikan sumbangan yang penting kepada siswa dalam pengembangan nalar, berfikir logis, sistematik, ktitis dan cermat, serta bersikap obyektif dan terbuka dalam menghadapi berbagai permasalahan.

Oleh karena itu matematika merupakan mata pelajaran yang terdapat dalam setiap jenjang pendidikan, baik pendidikan di lembaga formal maupun di lembaga non formal, bahkan di lembaga latihan kerja serta bidang lain yang berkaitan dengan tujuan peningkatan kualitas Sumber Daya Manusia (SDM) sekalipun.

Peningkatan itu juga sangatlah erat kaitannya dengan kurikulum yang diterapkan. Menurut Puspita (2013) kurikulum 2013 merupakan kurikulum berbasis kompetensi yang pernah digagas dalam rintisan Kurikulum Berbasis Kompetensi (KBK) 2004, tapi belum terselesaikan karena desakan untuk segera mengimplementasikan Kurikulum Tingkat Satuan Pendidikan (KTSP) 2006. Selain itu penataan kurikulum pada kurikulum 2013 dilakukan sebagai amanah dari UU No.20 tahun 2003 tentang pendidikan nasional dan peraturan presiden N0. 5 tahun 2010 tentang rencana pembangunan jangka menengah nasional.

Kurikulum 2013 dikembangkan untuk meningkatkan capaian pendidikan dengan dua strategi utama, yaitu peningkatan efektifitas pembelajaran pada satuan pendidikan dan penambahan waktu pembelajaran di sekolah. Efektifitas pembelajaran dicapai melalui tiga tahap, yaitu: (1) Efektifitas interaksi, akan tercipta dengan adanya harmonisasi iklim akademi dan budaya sekolah. Efektifitas interaksi dapat terjaga apabila kesinambungan manajemen dan kepemimpinan pada satuan pendidikan. (2) Efektifitas pemahaman, menjadi bagian penting dalam pencapaian efektifitas pembelajaran. Efektifitas tersebut dapat dicapai apabila pembelajaran yang mengedepankan pengalaman personal siswa melalui observasi, asosiasi, bertanya, menyimpulkan dan mengkomunikasikan. (3) Efektivitas penyerapan, dapat tercipta manakala adanya kesinambungan pembelajaran horizonta dan vertikal.

Penerapan kurikulum 2013 diimplementasikan adanya penambahan jam pelajaran, hal tersebut sebagai akibat dari adanya perubahan proses pembelajaran yang semula dari siswa diberi tahu menjadi siswa yang mencari tahu. Selain itu, akan merubah pula proses penialaiayang semula berbasis output menjadi berbasis proses dan output.

Orientasi kurikulum 2013 adalah terjadinya peningkatan dan keseimbangan antara kompetensi sikap, keterampilan dan pengetahuan. Hal itu sejalan dengan amanat UU no.20 tahun 2003 sebagai mana tersurat dalam penjelasan pasal 35: "kompetensi lulusan merupakan kualifikasi kemampuan lulusan yang mencakup sikap, pengetahuan, dan keterampilan sesuai dengan standar yang telah disepakati”. Hal ini sejalan pula dengan pengembangan kurikulum berbasis kompetensi yang telah dirintis pada tahun 2004 dengan mencangkup kompetensi sikap, pengetahuan, dan keterampilan secara terpadu. 
Hasil observasi peneliti di lapangan memberikan bayangan bahwa siswa kelas VII SMP Negeri di kota Makassar masih kurang kreatif, pemahaman, pola pikir dan penalaran matematik yang masih minim, serta siswa masih kesulitan dalam menghubungkan pelajaran matematik dengan situasi dunia nyata. Bahkan pada proses pembelajaran masih ada siswa yang tidur. Temuan tersebut tampaknya mengindikasikan bahwa pembelajaran yang digunakan oleh sebagian guru di sekolah belum banyak memberikan kesempatan kepada siswa untuk melakukan, mencoba, dan mengalami sendiri (learning to do). Dengan demikian prestasi hasil belajar masih dalam kategori sedang, hal ini dapat dilihat dari hasil ujian semester ganjil, dalam hal ini dapat dilihat dari data nilai rata-rata KKM siswa kelas VII SMP Negeri Akreditasi A di kota Makassar tahun pelajaran 2015/2016 yaitu masih sulit untuk mencapai 75 .

Penggunaan teori, model, pendekatan, metode atau strategi pembelajaran yang sesuai dapat mendorong tumbuhnya rasa senang siswa terhadap pelajaran, menumbuhkan dan meningkatkan pemahaman, kreatifitas, pola pikir dan penalaran matematik, serta menghubungkan materi pelajaran dengan situasi nyata dalam kehidupan sehari-hari dapat memberikan kemudahan bagi siswa untuk memahami pelajaran sehingga memungkinkan siswa mencapai hasil belajar yang lebih baik. Karena itu, melalui pemilihan model pembelajaran yang tepat guru dapat memilih atau menyesuaikan jenis pendekatan dengan karakteristik materi pelajaran yang disajikan.

Dari beberapa permasalahan di atas, maka ada tiga alternatif pendekatan yang dipilih oleh peneliti yaitu pendekatan saintifik, problem solving dan kontekstual. Peneliti menganggap bahwa pendekatan-pendekatan itu mampu mengatasi permasalahan-permasalahan tersebut. Namun demikian, perlu ada satu model pembelajaran yang mempayungi ketiga pendekatan di atas yaitu model pembelajaran kooperatif.

Pembelajaran bisa berjalan secara optimal, jika kondisi belajar siswa lebih aktif dalam meningkatkan eksplorasi investigasi, mengemukakan pendapat, saling membantu dan berbagi pendapat dengan teman untuk menyelesaikan masalah yang diberikan didalam pembelajaran. Salah satu cara untuk mengatasi hal diatas dan juga perbedaan individual siswa adalah belajar dengan kelompok-kelompok kecil yang disebut pembelajaran kooperatif (cooperative learning) (Slavin dalam Jusnawati, 2015:6). Pembelajaran kooperatif adalah suatu kelompok kecil yang bekerja sebagai suatu tim untuk menyelesaikan sebuah masalah, menyelesaikan suatu tugas, atau mengajarkan sesuatu untuk tujuan bersama lainnya. Dahlan (Jusnawati, 2015:7), menjelaskan cooperative learning bukan sekedar menempatkan siswa ke dalam kelompok-kelompok kecil untuk duduk bersama melainkan lebih menekankan pada kehadiran teman sebaya.

Pendekatan Saintifik (Scientific Approach) sangat sesuai dengan tujuan kurikulum yang diterapkan saat ini, sehingga tepat dipadankan dengan kurikulum yang sekarang hangat diperbincangkan dikalangan pendidik. Tujuan dari kurikulum yaitu untuk meningkatkan rasa ingin tahu siswa dan mendorong siswa untuk aktif. Pada kurikulum baru, siswa bukan lagi menjadi obyek tapi menjadi 
subyek dengan ikut mengembangkan tema yang ada. Dengan adanya perubahan ini, tentunya berbagai standar dalam komponen pendidikan akan berubah. Baik dari standar isi, maupun standar proses untuk meningkatkan kualitas.

Leeuw (Kurniawati, 2006:4) mengemukakan bahwa belajar melalui pendekatan problem solving pada hakikatnya adalah belajar berpikir (learning to think) dan belajar bernalar (learning to reason), yakni berpikir atau bernalar untuk mengaplikasikan pengetahuan-pengetahuan yang telah diperoleh sebelumnya dalam rangka memecahkan masalah-masalah baru yang belum pernah dijumpai. Pemecahan masalah (problem solving) dalam pembelajaran matematika merupakan hal terpenting karena matematika adalah ilmu pengetahuan yang logis, sistematis, mempunyai pola, abstrak dan harus dibuktikan.

Nurhadi (Rusman, 2010:189) berpendapat bahwa pembelajaran melalui pendekatan kontekstual merupakan konsep belajar yang dapat membantu guru mengaitkan antara materi yang diajarkan dengan situasi dunia nyata siswa dan mendorong siswa membuat hubungan antara pengetahuan yang dimilikinya dengan penerapannya dalam kehidupan mereka sebagai anggota keluarga dan masyarakat.

\section{METODE PENELITIAN}

\section{Jenis Penelitian}

Jenis penelitian yang digunakan pada penelitian ini adalah eksperimen. Eksperimen dilakukan terhadap tiga kelas, masing-masing diambil secara acak. Ketiganya diberikan tes awal kemudian diberikan perlakuan, setelah itu diberikan tes akhir. Selanjutnya ketiga kelas dievaluasi untuk melihat perubahan atau peningkatan yang terjadi terhadap hasil belajar matematika setelah mendapat perlakuan pembelajaran dengan pendekatan kontekstual, problem solving dan saintifik pada siswa kelas VII SMP Negeri Akreditasi A di Kota Makassar. Dengan Desain penelitian adalah Randomized pretest-postest comparison group design

\section{Variabel Penelitian}

Variabel dalam penelitian ini adalah sebagai berikut:

1. Variabel Bebas yaitu, pendekatan kontekstual,saintifik dan problem solving setting kooperatif

2. Variabel Terikat yaitu hasil belajar matematika, respons siswa, dan aktivitas siswa. Dimana :

a. Prestasi belajar siswa adalah nilai yang diperoleh setelah mengikuti serangkaian pembelajaran yang diukur dengan instrumen tes prestasi belajar.

b. Aktivitas siswa adalah rata-rata nilai siswa dari frekuensi semua aktivitas yang diukur dengan instrumen pengamatan aktivitas siswa.

c. Respons siswa adalah rata-rata dari nilai tanggapan siswa terhadap pembelajaran yang diukur dengan instrumen respon siswa. 
Satuan Eksperimen dan Perlakuan

Populasi dalam penelitian ini adalah semua siswa kelas VII SMP Negeri Akreditasi A di Kota Makassar. Sedangkan sampel penelitian dipilih 3 sekolah dan satu kelas setiap sekolah yang terpilih secara acak untuk diterapkan sebagai kelompok yang akan diberikan perlakuan pembelajaran matematika dengan menggunakan pendekatan kontekstual, saintifik, dan problem solving setting kooperatif. Pemilihan secara acak dilakukan karena kemampuan siswa diasumsikan homogen.

Teknik Analisis Data

Data yang akan dikumpulkan dalam penelitian ini adalah data tentang aktivitas siswa, respons siswa, dan hasil belajar siswa.

Penentuan skor rata-rata untuk setiap indikator keefektifan digunakan rubrik sebagai berikut.

Tabel 1. Rubrik penskoran masing-masing indikator keefektifan

\begin{tabular}{|c|c|c|}
\hline Hasil Belajar (HB) & $\begin{array}{c}\text { Aktivitas } \\
\text { Siswa (AS) }\end{array}$ & $\begin{array}{l}\text { Responss } \\
\text { Siswa (R) }\end{array}$ \\
\hline$\frac{X_{\text {past - Las }}+X_{\text {gain }}(100)+K K}{3}$ & $\frac{a_{1} A_{1}+a_{2} \Lambda_{1}+\ldots+a_{2} A_{A}}{a_{1}+a_{2}+\ldots .+a_{A}}$ & $\frac{r_{1} N_{1}+r_{2} K_{2}+\ldots+Y_{n 1}}{r_{1}+r_{2}+\ldots+r_{n}}$ \\
\hline$H^{\prime}=\frac{4}{100} \times H B$ & $E=\frac{3 H E^{\prime}+Z A S+K S}{6}$ & \\
\hline
\end{tabular}

Sumber: (Fadhilah, 2015:136)

Keterangan:

$\bar{X}_{\text {post-test }}=$ rata-rata hasil belajar siswa pada post-test

$\bar{X}_{\text {gain }} \quad=$ rata-rata gain ternormalisasi

$K K \quad=$ persentase ketuntasan klasikal

$a_{n} \quad=$ bobot aspek aktivitas siswa ke- $n$

$A_{n} \quad=$ rata-rata aspek aktivitas siswa ke- $n$

$r_{n} \quad=$ bobot aspek respons siswa ke- $n$

$R_{n} \quad=$ rata-rata aspek respons siswa ke- $n$

$E \quad=$ skor keefektifan pembelajaran

\section{HASIL PENELITIAN DAN PEMBAHASAN}

\section{Hasil Penelitian}

Indikator keefektifan yang dibandingkan pada analisis deskriptif adalah hasil belajar siswa, aktivititas siswa dalam pembelajaran dan respons siswa terhadap perangkat pembelajaran dan pembelajarannya. 


\section{Hasil belajar siswa}

Perbandingan skor hasil belajar siswa ditentukan dengan membandingkan rata-rata post-test, gain ternormalisasi dan persentase ketuntasan secara klasikal dapat dilihat pada Tabel 2.

Tabel 2. Perbandingan Hasil belajar Siswa Kelas Eksperimen Kesatu, Kedua dan Ketiga

\begin{tabular}{cccc}
\hline Kelas & Rata-rata post test & Gain & KK $(\%)$ \\
\hline Kontekstual & 84,17 & 0,75 & 90 \\
Problem Solving & 82,92 & 0,68 & 83 \\
Saintifik & 81,56 & 0,62 & 87 \\
\hline
\end{tabular}

Berdasarkan Tabel 2 dapat disimpulkan bahwa hasil belajar siswa pada kelas eksperimen yang diajar dengan pendekatan kontekstual lebih baik dari pada hasil belajar siswa pada eksperimen yang diajarkan dengan pendekatan problem solving setting kooperatif dan saintifik setting kooperatif.

\section{Aktivitas siswa}

Perbandingan aktivitas siswa ditentukan berdasarkan skor rata-rata aspek observasi pada masing-masing kelas eksperimen sebagaimana tampak pada Tabel 3.

Tabel 3. Perbandingan skor aktivitas siswa dalam pembelajaran

\begin{tabular}{ccc}
\hline Kelas & Skor Rata-Rata Total & Kategori \\
\hline Kontekstual & 3,55 & Sangat Baik \\
\hline Problem Solving & 3,51 & Sangat Baik \\
Saintifik & 3,44 & Baik
\end{tabular}

Berdasarkan Tabel 3 dapat disimpulkan bahwa aktivitas siswa pada kelas eksperimen yang diajar dengan pendekatan kontekstual lebih baik daripada aktivitas siswa pada eksperimen yang diajarkan dengan pendekatan problem solving setting kooperatif dan Saintifik yang ditandai dengan skor rata-rata total aktivitas siswa pada kelas eksperimen lebih besar daripada skor rata-rata aktivitas siswa pada kelas kontrol yakni 3,6 $>3,4$ dan 3,36 $<3,5$.

\section{Respons Siswa}

Perbandingan respons siswa ditentukan berdasarkan skor rata-rata respons siswa pada masing-masing kelas sebagaimana tampak pada Tabel 4.

Tabel 4. Perbandingan Skor Respons Siswa Terhadap Perangkat dan Pembelajaran

\begin{tabular}{ccc}
\hline Kelas & Skor Rata-Rata Total & Kategori \\
\hline Kontekstual & 3,5 & Positif \\
Saintifik & 3,1 & Cenderung Positif \\
Problem Solving & 3,3 & Cenderung Positif \\
\hline
\end{tabular}


Berdasarkan Tabel 4. dapat disimpulkan bahwa respons siswa pada kelas eksperimen yang diajar dengan pendekatan kontekstual lebih baik dari pada respons siswa pada kelas eksperimen yang diajar dengan pendekatan problem solving setting kooperatif dan saintifik yang ditandai dengan skor rata-rata total respons siswa pada kelas eksperimen pertama lebih dari skor rata-rata respons siswa pada kelas eksperimen kedua dan ketiga yakni 3,5 > 3,1 dan 3,1 <3,3.

Perbandingan pada Hasil Analisis Inferensial

Indikator keefektifan yang dibandingkan pada analisis inferensial adalah hasil belajar siswa berdasarkan hasil analisis inferensial. Analisis inferensial yang dilakukan diawali dengan beberapa uji prasyarat untuk data pree-test, post-test, dan gain ternormalisasi diantaranya uji normalitas dan uji homogenitas varians. Uji normalitas dilakukan untuk mengetahui apakah data berdistribusi normal atau tidak sedangkan uji homogenitas varians dilakukan untuk mengatahui kehomogenan varians dari populasi.

a. Uji Normalitas

Pengujian normalitas data dilakukan terhadap data hasil belajar pada kelas eksperimen pertama, kedua dan ketiga. Uji tersebut dilakukan dengan uji Shapiro-Wilk menggunakan program SPSS 20 for Windows dengan taraf signifikansi 0,05 .

\section{1) Uji Normalitas Data Pree-Test}

Setelah dilakukan pengolahan data, tampilan output uji normalitas data pre-test untuk kelas eksperimen pertama, kedua dan ketiga dapat dilihat pada Lampiran 7.

Berdasarkan hasil output uji normalitas varians dengan menggunakan uji Kolmogorov-Smirnov pada Lampiran 7, nilai signifikansi untuk kelas eksperimen pertama adalah 0,170 dan kedua adalah 0,102, serta menurut Shapiro-Wilk nilai signifikansi untuk kelas eksperimen ketiga adalah 0,140. Kerena nilai signifikansi ketiga kelas lebih dari 0,05, maka dapat dikatakan bahwa kelas eksperimen pertama, kedua dan ketiga berdistribusi normal.

\section{2) Uji Normalitas Data Post-test}

Setelah dilakukan pengolahan data, tampilan output uji normalitas data post-test untuk kelas eksperimen pertama, kedua dan ketiga dapat dilihat pada Lampiran 7.

Berdasarkan hasil output uji normalitas data dengan menggunakan uji Kolmogorov-Smirnov pada Lampiran 7, nilai signifikansi untuk kelas eksperimen pertama adalah 0,120, kedua adalah 0,064, dan ketiga adalah 0,200. Kerena nilai signifikansi ketiga kelas lebih dari 0,05, maka dapat dikatakan bahwa kelas eksperimen pertama, kedua dan ketiga berdistribusi normal. 
3) Uji Normalitas Data Gain Ternormalisai

Setelah dilakukan pengolahan data, tampilan output uji normalitas data post-test untuk kelas kontrol dan kelas eksperimen dapat dilihat pada Lampiran 7.

Berdasarkan hasil output uji normalitas data dengan menggunakan uji Kolmogorov-Smirnov pada Lampiran 7, nilai signifikansi untuk kelas eksperimen pertama adalah 0,158, kedua adalah 0,191 dan ketiga adalah 0,094. Karena nilai signifikansi ketiga kelas lebih dari 0,05, maka dapat dikatakan bahwa kelas eksperimen pertama, kedua dan ketiga berdistribusi normal.

b. Uji perbedaan peningkatan hasil belajar kelas eksperimen pertama, kedua dan ketiga

Hasil uji perbedaan kemampuan awal (pree-test) dan kemampuan akhir (post-test) menunjukkan bahwa kedua varians baik dari kelas eksperimen (pendekatan kontekstual, problem solving dan saintifik) memberikan keterangan pada tingkat kepercayaan 95\% dapat disimpulkan bahwa ketiga sampel berasal dari populasi yang homogen. Sehingga untuk uji yang digunakan adalah Anova.

Dari hasil uji Anova untuk mengetahui apakah ada perbedaan antara peningkatan hasil belajar matematika siswa pada kelas eksperimen pertama, kedua dan ketiga. Setelah dilakukan pengolahan data, tampilan output dapat dilihat pada Lampiran 7.

Hasil uji hipotesis yang dilakukan dengan Anova melalui program SPSS 20 dengan asumsi ketiga varians homogen (equal varians assumed) dan taraf signifikansi 0,05 , diperoleh ada perbedaan yang signifikan dari hasil belajar siswa yang diberikan pendekatan kontekstual dengan siswa yang diberikan pendekatan problem solving setting kooperatif dan saintifik. Hal ini dapat dilihat dari sig. $=$ 0,04 yang kurang dari nilai alpha $=0,05$.

Dari hasil perhitungan statistik diperoleh nilai gain yang signifikan yaitu untuk pendekatan kontekstual nilai gain $=0,75$, pendekatan saintifik setting kooperatif nilai gain $=0,62$ dan pendekatan problem solving setting kooperatif nilai gain $=0,68$ sehingga hipotesis kerja dapat disimpulkan sebagai berikut:

$$
H_{0}: \mu_{A} \leq \mu_{B} \text { dan } \mu_{B} \leq \mu_{C} \text { atau } H_{1}: \mu_{A}>\mu_{B} \text { dan } \mu_{B}>\mu_{C}
$$

Dari hipotesis kerja di atas dapat di simpulkan bahawa $\mathrm{H}_{0}$ ditolak dan $\mathrm{H}_{1}$ diterima. Dengan demikian dapat disimpulkan bahwa ditinjau dari hasil belajar, penerapan pembelajaran matematika dengan pendekatan kontekstual lebih baik daripada penerapan pembelajaran matematika dengan menggunakan pendekatan problem solving setting kooperatif dan saintifik pada materi bidang datar segiempat dan segitiga di kelas VII SMP Negeri Akreditasi A di Makassar.

c. Uji perbedaan persentase ketuntasan belajar kelas eksperimen pertama, kedua,dan ketiga

Hasil uji perbedaan persentase ketuntasan belajar siswa secara klasikal menunjukkan bahwa kedua varians baik dari kelas eksperimen pertama, kedua dan ketiga memberikan keterangan pada tingkat kepercayaan 95\% dapat disimpulkan bahwa ketiga sampel berasal dari populasi yang homogen. Berdasarkan hasil ketuntasan klasikal pada setiap kelas eksperimen terdapat perbedaan persentase ketuntasan siswa secara klasikal pada kelas eksperimen pertama dan kedua terhadap kelas eksperimen ketiga. Namun, walaupun demikian 
masih dapat disimpulkan bahwa secara inferensial hasil belajar matematika siswa pada kelas yang diajar melalui penerapan pendekatan kontekstual lebih tinggi dari pada kelas yang diajar dengan pendekatan problem solving setting kooperatif dan saintifik sehingga dapat disimpulkan penerapan pembelajaran matematika dengan menggunakan pendekatan kontekstual lebih baik daripada penerapan pembelajaran matematika dengan pendekatan problem solving setting kooperatif dan saintifik pada materi bidang datar segiempat dan segitiga di kelas VII SMP Negeri Akreditasi A di Makassar.

3. Analisis tingkat keefektifan pembelajaran

Hasil analisis tingkat keefektifan untuk masing-masing pembelajaran disajikan pada Tabel 5.

Tabel 5. Skor Indikator Keefektifan Secara Holistik

\begin{tabular}{ccccc}
\hline Kelas & $\begin{array}{c}\text { Hasil belajar } \\
\text { siswa }\end{array}$ & Aktivitas siswa & Respons siswa & E \\
\hline Kontekstual & 3,46 & 3,56 & 3,43 & 3,42 \\
Saintifik & 3,25 & 3,44 & 3,11 & 3,20 \\
Problem & 3,35 & 3,51 & 3,54 & 3,32 \\
$\quad$ Solving & & & \\
\hline
\end{tabular}

Adapun kategori keefektifan untuk masing-masing pembelajaran disajikan pada Tabel 6.

Tabel 6. Kategori Keefektifan Secara Holistik

\begin{tabular}{ccc}
\hline Kelas & E & Kateogori \\
\hline Kontekstual & 3,42 & Cukup efektif \\
Saintifik & 3,20 & Cukup efektif \\
Problem Solving & 3,32 & Cukup efektif \\
\hline
\end{tabular}

Berdasarkan tabel di atas, tampak bahwa keefektifan pada ketiga kelas eksperimen berada pada kategori cukup efektif . Berdasarkan analisis deskriptif yang dibuktikan dengan skor perolehannya ketiga kelas eksperimen dan analisis inferensial maka ketiga hipotesis mayor teruji kebenarannya, walaupun ketiganya berada pada kategori cukup sedang namun nilai efektifitas pendekatan kontekstual lebih dari pendekatan saintifik setting kooperatif dan pendekatan problem solving setting kooperatif, sehingga dapat disimpulkan bahwa kelas eksperimen pertama lebih efektif dari pada kelas eksperimen kedua dan ketiga.

\section{Hasil Pengujian Hipotesis}

Uji hipotesis dianalisis dengan menggunakan Anova untuk mengetahui perbandingan keefektifan pendekatan kontekstual, problem solving dan saintifik dalam pembelajaran matematika materi bidang datar segiempat dan segitiga. 
a. Uji hipotesis mayor

"Pembelajaran dengan menggunakan pendekatan kontekstual cukup efektif daripada pendekatan problem solving setting kooperatif dan saintifik dalam pembelajaran matematika materi bidang datar segiempat dan segitiga di kelas VII SMP Negeri Akreditasi A di Makassar"

Hipotesis mayor di atas dikatakan teruji kebenarannya apabila semua hipotesis minor di bawah ini teruji kebenarannya.

1) Hipotesis minor tentang prestasi belajar

a. Skor rata-rata posttes siswa setelah diajar dengan pendekatan kontekstual lebih tinggi daripada pendekatan problem solving setting kooperatif dan saintifik. Untuk keperluan statistik maka dirumuskan hipotesis kerja sebagai berikut:

$$
H_{0}: \mu_{B} \leq \mu_{C} \text { dan } \mu_{C} \leq \mu_{D} \text { atau } H_{1}: \mu_{B}>\mu_{C} \text { dan } \mu_{C}>\mu_{D}
$$

Berdasarkan analisis deskriptif menunjukkan bahwa rata-rata posttes siswa setelah diajar dengan pendekatan kontekstual lebih tinggi daripada pendekatan problem solving setting kooperatif dan saintifik dalam pembelajaran matematika materi bidang datar segiempat dan segitiga dan berdasarkan analisis inferensial menunjukkan bahwa $\mathrm{H}_{0}$ ditolak dan $\mathrm{H}_{1}$ diterima yang berarti rata-rata hasil belajar posttest pada kelas yang diajar dengan pendekatan kontekstual lebih tinggi daripada pendekatan problem solving setting kooperatif dan saintifik. Berdasarkan hasil analisis deskriptif dan analisis inferensial maka dapat simpulkan bahwa skor rata-rata posttes siswa setelah diajar dengan pendekatan kontekstual lebih tinggi daripada pendekatan problem solving setting kooperatif dan saintifik dalam pembelajaran matematika materi bidang datar segiempat dan segitiga

b. Peningkatan hasil belajar siswa yang diajar dengan model pembelajaran pendekatan kontekstual lebih tinggi daripada pendekatan problem solving setting kooperatif dan saintifik. Untuk keperluan statistik maka dirumuskan hipotesis kerja sebagai berikut:

$$
H_{0}: \mu_{B} \leq \mu_{C} \text { dan } \mu_{C} \leq \mu_{D} \text { atau } H_{1}: \mu_{B}>\mu_{C} \text { dan } \mu_{C}>\mu_{D}
$$

Berdasarkan analisis deskriptif menunjukkan bahwa rata-rata gain ternormalisasi siswa setelah diajar dengan pendekatan kontekstual lebih tinggi daripada problem solving dan saintifik dalam pembelajaran matematika materi bidang datar segiempat dan segitiga dan berdasarkan analisis inferensial menunjukkan bahwa $\mathrm{H}_{0}$ ditolak dan $\mathrm{H}_{1}$ diterima yang berarti rata-rata gain ternormalisasi siswa setelah diajar dengan model pendekatan kontekstual lebih tinggi daripada pendekatan problem solving setting kooperatif dan saintifik dalam pembelajaran matematika materi bidang datar segiempat dan segitiga. Berdasarkan hasil analisis deskriptif dan analisis inferensial maka dapat simpulkan bahwa rata-rata gain ternormalisasi siswa yang diajar dengan menggunakan pendekatan kontekstual tinggi daripada pendekatan problem solving setting kooperatif dan saintifik dalam pembelajaran matematika materi bidang datar segiempat dan segitiga.

c. Hasil uji perbedaan persentase ketuntasan belajar siswa secara klasikal menunjukkan bahwa ketiga pendekatan memberikan keterangan pada tingkat kepercayaan 95\% dapat disimpulkan bahwa ketiga sampel berasal dari populasi yang homogen. Sehingga pengujian dilakukan dengan menggunakan uji proporsi. 
Untuk uji proporsi dengan menggunakan taraf signifikan 5\% diperoleh $\mathrm{Z}$ tabel $=$ 1,645 , berarti $\mathrm{H}_{0}$ diterima jika $\mathrm{Z}$ hitung $\leq 1,645$. Karena diperoleh nilai $\mathrm{Z}$ hitung $=$ 0,0315, maka $\mathrm{H}_{0}$ diterima, artinya tidak ada perbedaan proporsi persentase ketuntasan siswa secara klasikal pada ketiga pendekatan yang diterapkan yaitu pendekatan kontekstual, pendekatan problem solving setting kooperatif dan saintifik. Berdasarkan uraian di atas, tidak ada perbedaan proporsi persentase ketuntasan siswa secara klasikal pada ketiga pendekatan. Walaupun demikian masih dapat disimpulkan bahwa secara inferensial prestasi belajar matematika siswa pada kelas yang diajar menggunakan pendekatan kontekstual lebih tinggi dari pada kelas yang diajar dengan menggunakan pendekatan problem solving setting kooperatif dan saintifik sehingga dapat disimpulkan penerapan pembelajaran matematika dengan pendekatan kontekstual cukup baik daripada penerapan pendekatan problem solving setting kooperatif dan saintifik pada pelajaran matematika materi bidang datar segiempat dan segitiga di kelas VIII SMP Negeri Akreditasi A di Kota Makassar.

2) Hasil Analisis aktivitas siswa

"Aktivitas siswa dengan menggunakan pendekatan kontekstual lebih tinggi daripada daripada pendekatan problem solving setting kooperatif dan saintifik dalam pembelajaran matematika materi bidang datar segiempat dan segitiga"

Berdasarkan hasil analisis deskriptif diperoleh rata-rata aktivitas siswa kelas VII SMP Negeri 24 Makassar yang diajar dengan menggunakan pendekatan kontekstual berada dalam kategori 3,56 "sangat baik" sedangkan rata-rata aktivitas siswa kelas VII SMP Negeri 13 Makassar dan kelas VII SMP Negeri 6 Makassar yang diajar dengan pendekatan problem solving setting kooperatif dan saintifik masing-masing berada dalam kategori 3,54 "sangat baik" dan kategori 3,44 "baik".

3) Hasil analisis respons siswa

"Respons siswa dengan menggunakan pendekatan kontekstual lebih tinggi daripada pendekatan problem solving setting kooperatif dan saintifik dalam pembelajaran matematika materi bidang datar segiempat dan segitiga"

Berdasarkan hasil analisis deskriptif diperoleh rata-rata skor respons siswa kelas VII SMP Negeri 24 Makassar yang diajar dengan pendekatan kontekstual adalah 3,51 yaitu berada dalam kategori "positif". Rata-rata skor respons siswa kelas VII SMP Negeri 13 Makassar yang diajar dengan pendekatan problem solving setting kooperatif adalah 3,38 yaitu berada dalam kategori "cenderung positif". Sedangkan rata-rata skor respons siswa kelas VII SMP Negeri 6 Makassar yang diajar dengan pendekatan saintifik setting kooperatif adalah 3,18 yaitu berada dalam kategori "cenderung positif".

Berdasarkan hasil analisis deskiptif dan hasil analisis inferensial yang telah diuraikan sebelumnya, tampak bahwa pendekatan kontekstual lebih tinggi daripada pendekatan problem solving setting kooperatif dan saintifik, baik dari prestasi belajar siswa, aktivitas siswa maupun respons siswa. Oleh karena itu, 
hipotesis mayor 3 teruji kebenarannya sehingga dapat disimpulkan bahwa Pembelajaran dengan menggunakan model pembelajaran pendekatan kontekstual cukup efektif daripada pendekatan problem solving setting kooperatif dan saintifik dalam pembelajaran matematika materi bidang datar segiempat dan segitiga di kelas VII SMP Negeri Akreditasi A di Kota Makassar.

Hasil analisis deskriptif meliputi keterlaksanaan model pembelajaran, prestasi belajar siswa, aktivitas siswa dan respons siswa. Sedangkan hasil analisis inferensial meliputi prestasi belajar siswa.

1. Analisis deskriptif

a. Keterlaksanaan Pendekatan

Berdasarkan hasil penelitian pada aspek keterlaksanaan pendekatan untuk ketiga pendekatan pembelajaran yaitu pendekatan kontekstual, pendekatan problem solving setting kooperatif dan saintifik, diperoleh fakta bahwa rata-rata keterlaksanaan pendekatan pendekatan kontekstual, pendekatan problem solving setting kooperatif dan saintifik masing-masing adalah 3,87 (kategori terlaksana dengan baik), 3,82 (kategori terlaksana dengan baik) dan 3,80 (kategori terlaksana dengan baik). Data tersebut menunjukkan bahwa keterlaksanaan pendekatan pembelajaran tersebut terlaksana dengan baik. Adapun selisih keterlaksanaan pendekatan kontekstual dengan Saintifik sebesar 0,05, selisih keterlaksanaan pendekatan kontekstual dengan problem solving sebesar 0,07 dan selisih keterlaksanaan pendekatan problem solving setting kooperatif dengan Saintifik sebesar 0,02, ketiga selisih tersebut merupakan angka kecil yang mengindikasikan bahwa persentase keterlaksanaan ketiga pendekatan dianggap sama sehingga layak untuk dibandingkan keefektifannya.

Adanya perkembangan dan perbedaan keterlaksanaan ketiga pendekatan sebagai akibat adanya pembelajaran dari pengalaman sebelumnya. Namun dari ketiga pendekatan yang diterapkan pada siswa kelas VII SMP Negeri Akreditasi A di kota Makassar keterlaksanaan pembelajaran pendekatan kontekstual setting kooperatif lebih baik daripada pendekatan problem solving dan saintifik setting kooperatif.

b. Prestasi belajar siswa

Secara deskriptif prestasi belajar dari ketiga pendekatan yang diterapkan pada siswa kelas VII SMP Negeri Akreditasi A di kota Makassar adalah sebagai berikut:

1. Skor rata-rata prestasi belajar siswa untuk post test melalui pendekatan kontekstual, problem solving dan saintifik setting kooperatif berturut-turut adalah 84,2, 83, dan 81,5. Skor rata-rata post test dari ketiga pendekatan tersebut melebihi KKM yaitu 75 dan nampak bahwa skor rata-rata pembelajaran pendekatan kontekstual setting kooperatif lebih tinggi daripada pendekatan problem solving dan saintifik setting kooperatif.

2. Rata-rata gain ternormalisasi minimal pendekatan kontekstual, problem solving dan saintifik setting kooperatif berturut-turut adalah 0,8 (klasifikasi tinggi), 0,7 (klasifikasi tinggi) dan 0,6 (klasifikasi sedang). Rata-rata gain ternormalisasi minimal pembelajaran menunjukkan 
pendekatan kontekstual setting kooperatif lebih tinggi daripada pendekatan problem solving dan saintifik setting kooperatif.

3. Ketuntasan siswa secara klasikal pendekatan pendekatan kontekstual, problem solving dan saintifik setting kooperatif berturut-turut adalah $90 \%$, $83 \%$, dan $87 \%$. Ketiga pendekatan pembelajaran diatas dikatakan cukup efektif karena ketuntasan belajar lebih dari $80 \%$. Ketuntasan siswa secara klasikal menunjukkan persentase pendekatan kontekstual setting kooperatif lebih efektif daripada pendekatan problem solving dan saintifik setting kooperatif.

Secara deskriptif menunjukkan bahwa prestasi belajar siswa dengan menggunakan pendekatan kontekstual setting kooperatif lebih baik dibandingkan pendekatan pendekatan problem solving dan saintifik setting kooperatif.

c. Aktivitas siswa

Hasil pengamatan observer terhadap aktivitas siswa terhadap pendekatan kontekstual pada kelas eksperimen pertama, menunjukkan bahwa dari ketujuh aspek yang diamati kesemuanya memenuhi kategori sangat baik. Pendekatan problem solving setting kooperatif pada kelas eksperimen kedua, menunjukkan bahwa dari ketujuh aspek yang diamati 1 aspek berada pada kategori baik dan 6 aspek memenuhi kategori sangat baik. Sedangkan pada pendekatan saintifik setting kooperatif pada kelas eksperimen ketiga, menunjukkan bahwa dari ketujuh aspek yang diamati 2 aspek memenihi kategori sangat baik dan 5 aspek memenuhi kategori baik.

Aktivitas siswa pada pendekatan kontekstual berlangsung secara optimal. Pada umumnya siswa antusias dalam mengikuti pembelajaran dengan menggunakan pendekatan kontekstual, pendekatan problem solving setting kooperatif dan saintifik. Namun aktivitas siswa pada pendekatan kontekstual setting kooperatif lebih baik daripada pendekatan problem solving dan saintifik setting kooperatif.

\section{d. Hasil pengamatan terhadap respons siswa}

Berdasarkan hasil angket respons siswa, secara keseluruhan memberi respons siswa positif terhadap pembelajaran. Pada pembelajaran dengan menggunakan pendekatan kontekstual 3,51 termasuk dalam kategori positif, pada pembelajaran dengan menggunakan pendekatan problem solving setting kooperatif 3,38 termasuk dalam kategori cenderung positif dan pembelajaran dengan menggunakan pendekatan saintifik setting kooperatif 3,18 termasuk dalam kategori cenderung positif. Perolehan respons siswa telah memenuhi kriteria keefektifan, artinya hampir seluruh siswa memberikan respons positif terhadap ketiga pendekatan pembelajaran tersebut. Meskipun demikian, dilihat dari besarnya respons siswa dengan menggunakan pendekatan kontekstual lebih besar dari pada respons siswa dengan menggunkan pendekatan problem solving dan saintifik setting kooperatif. 
Secara deskriptif prestasi belajar siswa, aktivitas siswa dan respons siswa dengan menggunakan pendekatan kontekstual setting kooperatif lebih baik daripada pendekatan problem solving setting kooperatif dan saintifik setting kooperatif.

\section{Analisis inferensial}

Secara inferensial hasil belajar dari ketiga pendekatan yang diterapkan pada siswa kelas VII SMP Negeri Akreditasi A di kota Makassar adalah sebagai berikut:

a. Skor rata-rata prestasi belajar siswa untuk post test melalui pendekatan kontekstual, problem solving dan saintifik setting kooperatif berturut-turut adalah 84,2, 83, dan 81,5. Pada lampiran 7 menunjukkan ketiga pendekatan tesebut memiliki nilap $\mathrm{p}<0,001$ yang mengindikasikan skor rata-rata post test dari ketiga pendekatan tersebut melebihi KKM yaitu 75. Sehingga dapat disimpulkan bahwa skor rata-rata pembelajaran dengan menggunakan pendekatan kontekstual setting kooperatif lebih baik daripada pendekatan problem solving dan saintifik setting kooperatif.

b. Rata-rata gain ternormalisasi minimal pendekatan kontekstual, problem solving dan saintifik setting kooperatif berturut-turut adalah 0,8 (klasifikasi tinggi), 0,7 (klasifikasi tinggi) dan 0,6 (klasifikasi sedang). Rata-rata gain ternormalisasi minimal dari ketiga pendekatan pembelajaran mengalamai peningkatan prestasi belajar siswa yaitu skor rata-rata post test lebih besar daripada skor rata-rata pre test dimana nilai rata-rata gainnya lebih dari 0,29. Dengan demikian peningkatan prestasi belajar pendekatan kontekstual setting kooperatif lebih baik daripada pendekatan problem solving dan saintifik setting kooperatif.

c. Ketuntasan siswa secara klasikal dilakukan dengan menggunakan uji proporsi. Untuk uji proporsi dengan taraf signifikansi $5 \%, Z$ tabel $_{(1,64)}=0,45$. Pendekatan kontekstual dan saintifik setting kooperatif diperoleh $Z$ hitung $=0,77>Z$ tabel $_{(1,64)}=0,4$ maka $H_{0}$ ditolak dan $H_{1}$ diterima maksudnya proporsi siswa yang mencapai kriteria ketuntasan 75 mencapai $84,9 \%$ dari keseluruhan siswa yang mengikuti tes. Sedangkan pendekatan problem solving setting kooperatif diperoleh $Z$ hitung $=-0,24<Z$ tabel $_{(1,64)}=0,4$, maka $H_{1}$ ditolak dan $H_{0}$ diterima maksudnya proporsi siswa yang tidak mencapai kriteria ketuntasan 75 mencapai $84,9 \%$ dari keseluruhan siswa yang mengikuti tes.

Setelah membandingkan hasil post test, gain ternormalisasi dan ketuntasan klasikal pada ketiga pendekatan tersebut dengan menggunakan uji- $t$, diperoleh bahwa $\mathrm{H}_{0}$ ditolak dan $\mathrm{H}_{1}$ diterima dengan demikian pada pendekatan kontekstual setting kooperatif lebih baik dibandingkan pendekatan problem solving dan saintifik setting kooperatif.

Berdasarkan hasil deskriptif dan inferensial, efektivitas pembelajaran berdasarkan 3 (tiga) indikator yakni (1) hasil belajar antara siswa yang diajar dengan menggunakan pendekatan kontekstual setting kooperatif lebih baik daripada pendekatan problem solving dan saintifik setting kooperatif, (2) aktivitas siswa yang diajar dengan menggunakan pendekatan pendekatan kontekstual 
setting kooperatif lebih baik daripada pendekatan problem solving dan saintifik setting kooperatif, dan (3) respons antara siswa setelah diajar dengan menggunakan pendekatan pendekatan kontekstual setting kooperatif lebih baik daripada pendekatan problem solving dan saintifik setting kooperatif. Dengan demikian secara umum penerapan pendekatan pendekatan kontekstual setting kooperatif lebih efektif daripada pendekatan problem solving dan saintifik setting kooperatif pada siswa kelas VII SMP Negeri Akreditasi A di kota Makassar.

\section{SIMPULAN DAN SARAN}

\section{Simpulan}

Kesimpulan yang dapat ditarik pada penelitian ini berdasarkan dari ketiga indikator keefektifan yaitu (1) hasil belajar siswa, (2) aktivitas siswa dalam pembelajaran, dan (3) respons siswa terhadap pembelajaran.

1. Pendekatan kontekstual setting kooperetif efektif diterapkan pada pembelajaran matematika Siswa Kelas VII SMP Negeri akreditasi A di kota Makassar

2. Pendekatan problem solving setting kooperetif efektif diterapkan pada pembelajaran matematika Siswa Kelas VII SMP Negeri akreditasi A di kota Makassar

3. Pendekatan saintifik setting kooperetif efektif diterapkan pada pembelajaran matematika Siswa Kelas VII SMP Negeri akreditasi A di kota Makassar

4. Penerapan pendekatan kontekstual lebih efektif dibandingkan dengan pendekatan problem solving dan pendekatan saintifik setting kooperatif pada pembelajaran matematika Siswa Kelas VII SMP Negeri akreditasi A di kota Makassar

\section{DAFTAR PUSTAKA}

Hasmiati. 2013. Efektifitas Pembelajaran Matematika Realistik Dengan Setting Kooperatif Tipe TEAM dan Tipe TGT Materi Volume Bangun Ruang pada Kelas V SD Inpres Bakung II. Tesis Tidak Diterbitkan. Makassar: PPs UNM.

Sugiyono. 2012. Metode Penelitian Pendidikan Pendekatan Kualitatif, Kuantitatif, dan $R$ \& D. Bandung: Alfabeta

Sanjaya, Wina. 2007. Strategi Pembelajaran. Jakarta. Kencana.

Soedjadi, R. 2000. Kiat Pendidikan Matematika di Indonesia.Jakarta: Direktorat Jenderal Pendidikan Tinggi Departemen Pendidikan Nasional.

Undang-Undang Pendidikan Nasional No. 22 Tahun 2003 tentang Standar Isi Untuk Pendidikan Dasar dan Menengah

(http://bsnp-indonesia.org/id/wpcontent/uploads/isi/Permen_22_2006.pdf).

Diakses tanggal 12 November 2013 